\title{
Advanced development of the cystacanths of Neoechinorhynchus beringianus (Eoacanthocephala: Neoechinorhynchidae) living in intermediate hosts
}

\author{
E.I. Mikhailova1, K.V. Kusenko² \\ Institute of Biological Problems of the North, Far Eastern Branch of the Russian Academy of \\ Sciences, Portovaya Str., 18, Magadan 685000 Russia.E-mails: (1) emmodus@gmail.com (2) \\ kusenko.kseniya@yandex.ru
}

\begin{abstract}
This study of naturally infected ostracods revealed advanced sexual development in cystacanths of $N$. beringianus and detected signs of maturation of both female and male acanthocephalans in intermediate hosts. In addition, the study observed ultrastructural evidence of the presence of mature spermatozoa in the seminal vesicles of male cystacanths and of the formation of secretory granules in their cement glands. The study provides quantitative data on the occurrence of advanced development of cystacanths in intermediate hosts and of the immaturity of acanthocephalans in definite hosts. Furthermore, the study considers the temperature conditions for larval development of $N$. beringianus in the natural population and the probable dependence of cystacanths' maturation rate on these conditions. Finally, the study discusses the biological significance of the phenomenon detected.

How to cite this article: Mikhailova E.I., Kusenko K.V. 2018. Advanced development of the cystacanths of Neoechinorhynchus beringianus (Eoacanthocephala: Neoechinorhynchidae) living in intermediate hosts // Invert. Zool. Vol.15. No.1. P.92-102. doi: 10.15298/invertzool.15.1.07
\end{abstract}

KEY WORDS: Acanthocephala, Neoechinorhynchus, intermediate host, advanced development.

\section{Опережающее развитие цистакантов Neoechinorhynchus beringianus (Eoacanthocephala, Neoechinorhynchidae) в промежуточных хозяевах}

\section{Е.И. Михайлова ${ }^{1}$, К.В. Кусенко²}

Институт биологических проблем Севера ДВО РАН, ул. Портовая, 18, Магадан 685000, Poccuя. E-mails: (1)emmodus@gmail.com (2) kusenko.kseniya@yandex.ru

РЕЗЮМЕ: В процессе изучения спонтанной инвазии остракод скребнем $N$. beringianus было обнаружено продвижение в половом развитии цистакантов. Признаки полового созревания скребней в промежуточных хозяевах выявлены у самок и у самцов. Приведены ультраструктурные свидетельства присутствия зрелых сперматозоидов в семенном пузырьке и гранул секрета в цементной железе самца. Представлены количественные данные о встречаемости в промежуточных хозяевах продвинутых в половом развитии цистакантов и неполовозрелых скребней в кишечниках дефинитивных хозяев. Рассмотрены температурные условия, в которых протекает личиноч- 
ное развитие скребней $N$. beringianus в природе, и вероятная зависимость темпов полового созревания цистакантов от этих условий. Обсуждается биологическое значение обнаруженного явления.

Как цитировать эту статью: Mikhailova E.I., Kusenko K.V. 2018. Advanced development of the cystacanths of Neoechinorhynchus beringianus (Eoacanthocephala: Neoechinorhynchidae) living in intermediate hosts // Invert. Zool. Vol.15. No.1. P.92-102. doi: 10.15298/invertzool.15.1.07

КЛЮЧЕВЫЕ СЛОВА: Acanthocephala, Neoechinorhynchus, промежуточный хозяин, опережающее развитие.

\section{Introduction}

The modern group of worms that were separated into phylum Acanthocephales by Skrjabin and Schulz (Skrjabin, Schulz, 1940; Petrochenko, 1956) includes exclusively parasitic forms. Their life cycle consists of two stages that take place sequentially in intermediate and definitive hosts. Regarding the evolution of the parasites' life cycles, Chubb et al. (2010) noted that the propagule stage of acanthocephalans occurs only in definitive hosts. Parthenogenesis, or neoteny, was not observed in representatives of this phylum.

In all acanthocephalan species, development of female gonads is completed by forming from ovarian primordium free-floating ovarian balls containing mature oocytes. Several reports have noted that fragmentation of ovarian tissue can occasionally occur in intermediate hosts (Crompton, 1985). Precocious ovarian fragmentation into ovarian balls at the late acanthella stages or incompletely developed cystacanths in intermediate hosts were noted by Moore $(1946,1962)$ and Asaolu et al. (1981) in archiacanthocephalans Moniliformis moniliformis (Bremser, 1811) Travassos, 1915 and Mediorhynchus grandis Van Cleave, 1916, by Petrochenko (1956) in palaeacanthocephalans Polymorphus magnus Skrjabin, 1913 parasitizing in warmblooded definitive hosts and also by Awachie (1966) in palaeacanthocephalans Echinorhynchus truttae Schrank, 1788, by Andryuk (1979a, b) in Acanthocephalus anguillae (Müller, 1780) Lühe, 1911 and in A. lucii (Müller, 1776) Lühe, 1911 and by Amin et al. (1980) in A. dirus (Van Cleave, 1931) Van Cleave et Townsend, 1936, whose adult stages develop in fish. Unlike representatives of the two classes mentioned, eoacanthocephalan cystacanths of Paulisentis fractus Van Cleave et Bangham, 1949, P. missouriensis Keppner, 1974, Neoechinorhynchus saginatus Van Cleave et Bangham, 1949 and Octospiniferoides chandleri Bullock, 1957, infectivity with which have been experimentally supported (Cable, Dill, 1967; Keppner, 1974; Uglem, Larson, 1969; DeMont, Corkum, 1982, respectively) contained one compact ovary, as well as cystacanths Tanaorhamphus longirostris (Van Cleave, 1913) Ward, 1918 from naturally infected copepods (Wilson, Hubschman, 1985).

Regarding male acanthocephalans, a few observations have indicated the possibility of their maturation in intermediate hosts. Nickol \& Heard (1973) reported that Fessisentis necturorum Nickol, 1967, whose adult stage parasitize larval salamanders “....develops nearly to maturity within the intermediate host. ...Vasa deferentia and seminal vesicles of male cystacanths stained very darkly indicating possible presence of semen". Examining male cystacanths of $A$. lucii, Brattey $(1980,1986)$ noted that the parasites fully developed sexually in the intermediate host, since motile spermatozoa were seen in the testes.

The development of testes and gametogenesis in Acanthocephala have been studied mainly in adult-stage individuals from the intestines of definitive hosts (Crompton, 1985). Cytological organization of spermatozoa is known in representatives of several species in three classes of phylum and recognized to be generally similar for all acanthocephalans (Crompton, 1985; Schmidt-Rhaesa, 2007). However, cytological 
studies of the male reproductive system in worms from intermediate hosts still are rare. Available works show that spermatogenesis in the testes of Polymorphus minutus (Goeze, 1782) Lühe, 1911 begins only after the cystacanths reach their definitive hosts (Whitfield, 1971). The formation of secretory granules in cystacanths' cement glands while still in the intermediate hosts has not been detected by Dezfuli et al. (1998) in the species Pomphorhynchus laevis (Zoega in Müller, 1776) Van Cleave, 1924 but has been reported in A. anguillae (Dezfuli et al., 2001).

During a study of natural infection with $N$. beringianus Mikhailova et Atrshkevich, 2008 of intermediate hosts, we found features of advanced sexual development in cystacanths of this species. The aim of the present work was to demonstrate these features and confirm by cytological data the fact of maturation of males in intermediate hosts. In addition, we attempted to estimate the extent of the phenomenon of advanced sexual development in populations of acanthocephalans inhabiting northeastern Asia.

\section{Materials and methods}

The materials used were obtained from two habitats of $N$. beringianus in northeastern Russia: Lake Chernoye in the Kolyma River basin $\left(61^{\circ} 01^{\prime} \mathrm{N}, 151^{\circ} 44^{\prime} \mathrm{E}\right)$ and a shallow freshwater pond near the northern coast of the Sea of Okhotsk $\left(59^{\circ} 42^{\prime} \mathrm{N}, 150^{\circ} 00^{\prime} \mathrm{E}\right)$.

The average monthly air temperature values are given according to the weather station nearest the study area $\left(61^{\circ} 07^{\prime} \mathrm{N}, 152^{\circ} 24^{\prime} \mathrm{E}\right)$ (Weather archive in Talaya. URL: http://rp5.ru/ Weather_archive_in_Talaya).

Cystacanths of $N$. beringianus were recovered from ostracods of the genus Candona that were sampled with a $0.4-\mathrm{mm}$ mesh net. The adult worms were recovered from ninespine sticklebacks Pungitius pungitius (L.) caught in bottom traps.

To determine the number of ostracods infected, they were fixed in $70 \%$ alcohol and dissected. To study their stage of maturity, the cystacanths were recovered from live ostracods and extended in tap water. Then, the acanthocephalans were placed in $70 \%$ alcohol. The worms removed from fish intestines were processed the same way. Glycerin was used as a clearing agent. Worm whole mounts and live cystacanths were examined using a Carl Zeiss Axiolab Imager. D1 light microscope.

For examination with transmission electron microscopy (TEM), cystacanths of $N$. beringianus obtained from live ostracods were fixed in $2 \%$ glutaraldehyde in $0.1 \mathrm{M}$ of sodium buffer ( $\mathrm{pH} 7.2$ ), post-fixed in $1 \%$ osmium tetroxide in the same buffer for $2 \mathrm{~h}$, dehydrated in a graded ethanol series and then embedded in an EponAraldite mixture. Semi-thin sections were cut on an LKB-4 ultra-microtome with glass knives, stained with methylene blue and crystal violet mixture and observed with an Olympus CX41. Ultra-thin sections were obtained with a PowerTome PT-PC ultra-microtome with glass knives, stained with uranyl acetate and observed with a JEM 1400 Plus electron microscope.

The term 'juvenile' refers to males having no sperm and females having no developing embryos in their body cavities. The term cystacanth refers only to individuals located within intermediate hosts.

\section{Results}

Study of the wild population of $N$. beringianus in Lake Chernoye began in 1999 and persists to the present. At any time during the warm season, the worms are present both in intermediate and definitive hosts. Between 1999 and 2015, 13 samples of ostracods from this lake were analyzed, and the prevalence varied from 5.2-98.8\%. Annual sampling of sticklebacks demonstrated the permanently high prevalence of infection, which ranged from $72-100 \%$.

Small ponds near the northern coast of the Sea of Okhotsk are also typical habitats for $N$. beringianus. One of them was investigated between 1996 and 2006. In 5 samples of ostracods, prevalence varied from $0.5-23.2 \%$. In 4 samples of sticklebacks, prevalence varied from $12-48 \%$. 


\section{Reproductive systems of cystacanths and juveniles}

Live cystacanths of $N$. beringianus were obtained from naturally infected ostracods $\mathrm{Can}$ dona acuminata (Fisch), 1851. After the shells of the crustaceans were damaged, the worms began moving vigorously and finally emerged (Fig. 1A, B).

The light microscopic study of cystacanths revealed that many females had ovarian balls (Figs 1B, 2A) and some males had secretionfilled cement reservoirs and seminal vesicles (Figs 1A, 2C). Likewise, in the population living in the coastal pond, secretion-filled seminal vesicles were observed in males located in intermediate hosts. Fig. 2D shows a mature male cystacanth with its host ostracod, C. stagnalis G.O. Sars, 1890 from this habitat.

At the same time, all samples contained specimens whose reproductive systems were less developed. Some females had ovaries that had not yet fragmented, and developed in the following sequence. First, the ovary looks like a dense ovoid structure (Fig. 3A), then it increases in size and becomes more friable while maintaining a spherical shape (Fig. 3C), and then it elongates (Fig. 3D). Elongation is followed by fragmentation (Fig. 3E). Probably, the ovaries move freely in the females' body cavities, since they were found in both ventral and dorsal ligament sacs (Fig. 3A, B). In the least sexually developed males, there is no visible content in the vasa deferentia, and the seminal vesicle bulges were not observed (Fig. 2B).

Similar to cystacanths from intermediate hosts, samples of adult-stage worms obtained from definitive hosts contained juvenile females with unfragmented ovaries (Fig. 4A) and immature males without sperm (Fig. 4B).

Fine structure of male cystacanths' reproductive organs

The reproductive system of male cystacanth $N$. beringianus was observed in semi-thin sections of their posterior ends and were characterized by fully developed organs (Fig. 5).

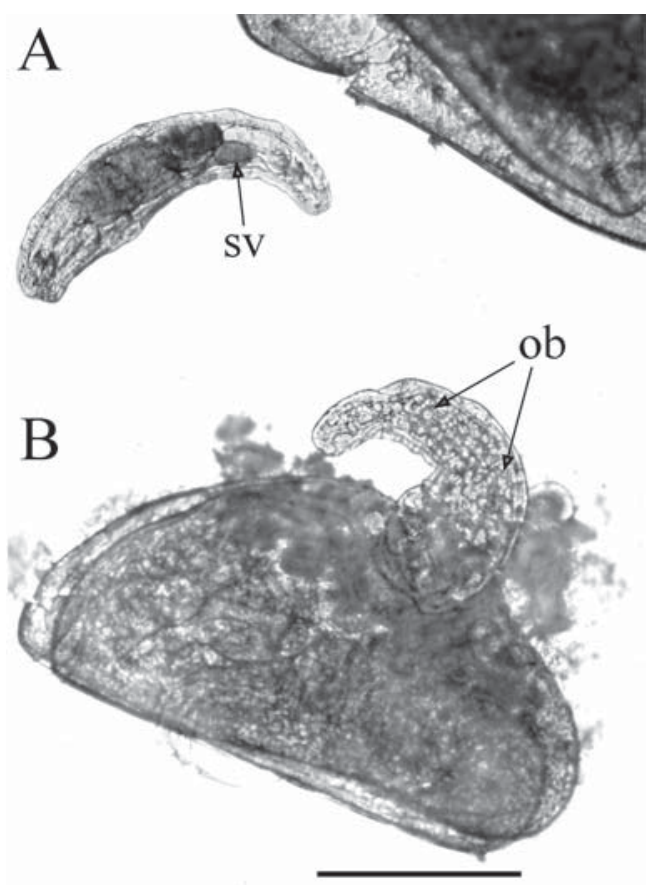

Fig. 1. Cystacanths of Neoechinorhynchus beringianus with their intermediate hosts. A-B - light microscopy, whole mounts. A - mature male; $\mathrm{B}$ female.

Abbreviations: ob — ovarian balls; $\mathrm{sv}$ - seminal vesicle. Scale bar: $0.5 \mathrm{~mm}$.

Рис. 1. Цистаканты Neoechinorhynchus beringianus со своими промежуточными хозяевами. А-В тотальные препараты (световая микроскопия). А - зрелый самец; В - самка.

Обозначения: ob - зародышевые шары; sv - семенной пузырек. Масштаб: 0,5 мм.

The cement reservoir contained opaque secretions, and the seminal vesicle was filled with a substance having a cellular appearance. The tegument surrounded the organs very closely, probably as the result of fixation.

The area where the cement gland contacts the seminal vesicle and Saefftigen's pouch (in Fig. 5 marked with a frame) was studied using TEM. In the seminal vesicle, free flagella were visible and observed to contain axonemes consisting of microtubules in a $9+2$ pattern (Fig. $6 \mathrm{~B}, \mathrm{C})$. In the spermatozoa, protein granules (Fig. 6B) and chromatin were present, while mitochondria were absent. Electron-dense laminae of condensed chromatin were situated in 


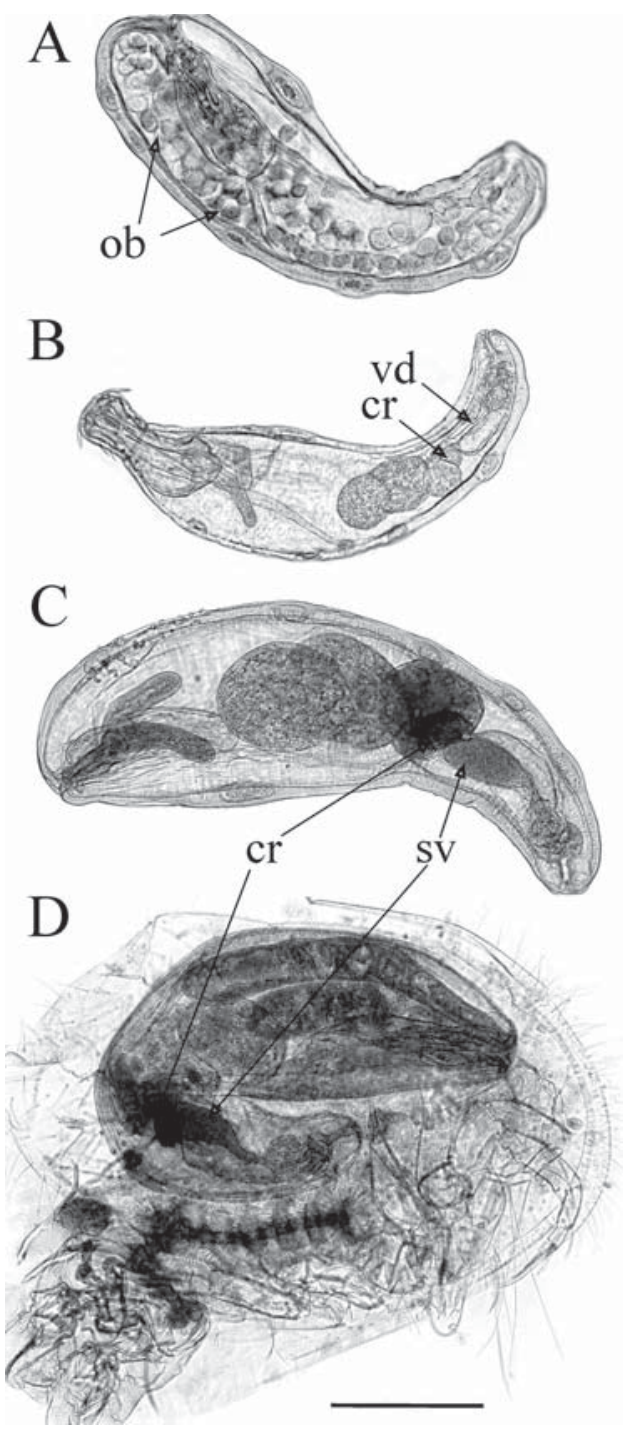

Fig. 2. Cystacanths of Neoechinorhynchus beringianus from Lake Chernoye and coastal pond. A-D light microscopy, whole mounts. A-C - cystacanths from Lake Chernoye; A - female with ovarian balls; $\mathrm{B}$ - immature male; $\mathrm{C}$ - mature male; $\mathrm{D}$ - mature male in ostracod from coastal pond.

Abbreviations: $\mathrm{cr}$ - cement reservoir; ob — ovarian balls; sv — seminal vesicle; vd — vas deferens. Scale bar: $0.25 \mathrm{~mm}$. Рис. 2. Цистаканты Neoechinorhynchus beringianus из оз. Черное и из озера на морском побережье. $\mathrm{A}-\mathrm{D}$ - тотальные препараты (световая микроскопия). $\mathrm{A}-\mathrm{C}$ - цистаканты из оз. Черное; $\mathrm{A}-$ самка с зародышевыми шарами; В - незрелый самец; C - зрелый самец; D - зрелый самец в ракушковом раке из озера на морском побережье. Обозначения: $\mathrm{cr}$ - цементный резервуар; ob - зародышевые шары; sv - семенной пузырек; vd - семявыводящие каналы. Масштаб: 0,25 мм.

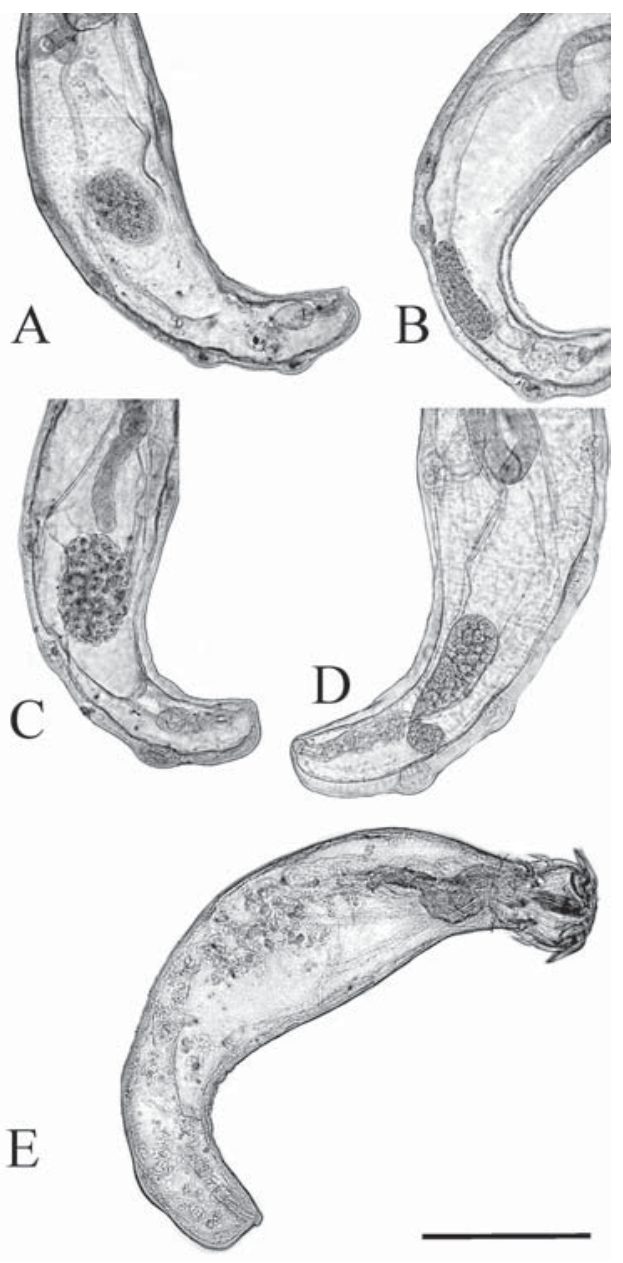

Fig. 3. Changes of ovarian tissue in female cystacanths of Neoechinorhynchus beringianus. A-E - light microscopy, whole mounts. A - posterior end of worm with ovary within ventral ligament sac; B posterior end of worm with ovary within dorsal ligament sac; C - posterior end of worm with friable ovary; D - posterior end of worm with elongated ovary; E - worm with fragmented ovarian tissue. Scale bar: $0.25 \mathrm{~mm}$.

Рис. 3. Изменения яичника у цистакантов Neoechinorhynchus beringianus женского пола. А-Е тотальные препараты (световая микроскопия). $\mathrm{A}$ - задний конец самки с компактным яичником в вентральном лигаментном мешке; В задний конец самки с яичником в дорсальном лигаментном мешке; $\mathrm{C}$ - задний конец самки с рыхлой тканью в яичнике; D - задний конец самки с удлинившимся яичником; E - самка после фрагментации яичника на зародышевые шары. Масштаб: 0,25 мм. 


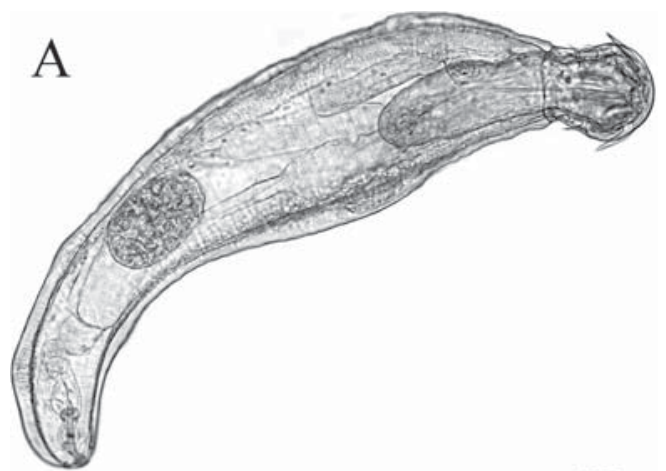

Fig. 4. Immature juveniles of Neoechinorhynchus beringianus from fish intestine. A-B - light microscopy, whole mounts. A - female with unfragmented ovary; B - male without sperm. Scale bar: $0.25 \mathrm{~mm}$.

Рис. 4. Незрелые ювенильные особи Neоесhinorhynchus beringianus из кишечника рыбы. АВ - тотальные препараты (световая микроскопия). А - самка с цельным яичником; В - самец без спермы. Масштаб: 0,25 мм.
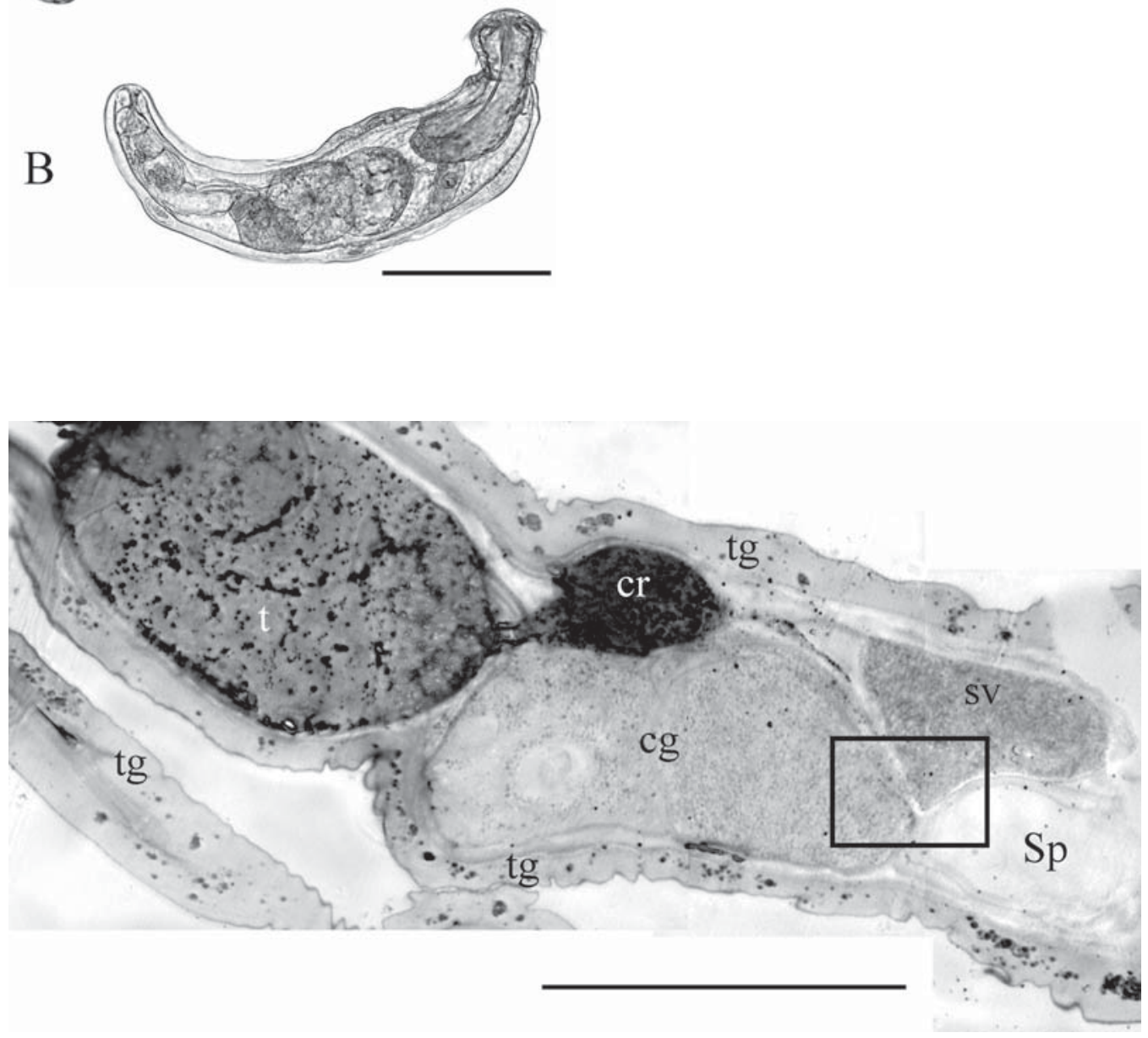

Fig. 5. Posterior end of male cystacanth of Neoechinorhynchus beringianus. Light microscopy, semi-thin sections. The framed part is shown in Fig. 6A.

Abbreviations: $\mathrm{cg}$ - cement gland; $\mathrm{cr}$ - cement reservoir; $\mathrm{Sp}$ - Saefftigen's pouch; sv — seminal vesicle; $\mathrm{t}$ - testis; tg — tegument. Scale bar: $100 \mu \mathrm{m}$.

Рис. 5. Задний конец цистаканта Neoechinorhynchus beringianus мужского пола. Полутонкие срезы (световая микроскопия). Область в рамке изображена на рис. 6А.

Обозначения: cg - цементная железа; cr - цементный резервуар; $\mathrm{Sp}$ - мешок Сэфтигена; sv - семенной пузырек; $\mathrm{t}$ - семенник; $\mathrm{tg}$ - тегумент. Масштаб: 100 мкм. 


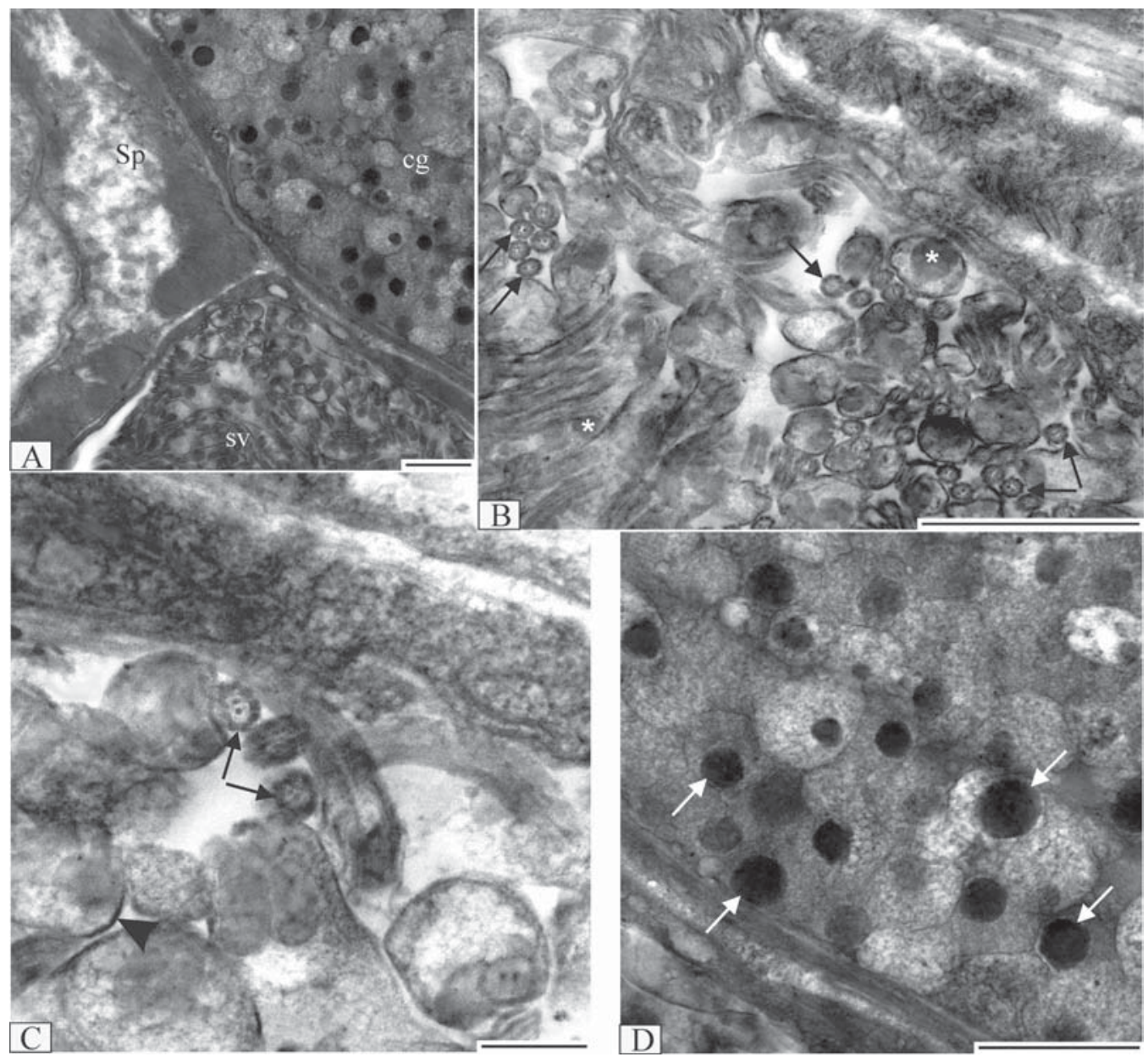

Fig. 6. Ultrastructure of seminal vesicle and cement gland of cystacanth of Neoechinorhynchus beringianus. A-D - electron microscopy. A - longitudinal section showing cement gland, Saefftigen's pouch, seminal vesicle; $\mathrm{B}$ - the part of seminal vesicle showing protein granules (asterisks) and spermatozoan flagella (arrows); C - high magnification of part of seminal vesicle showing spermatozoan flagella (arrows), chromatin condensation (arrowhead); D - high magnification of part of cement gland with cement granules (arrows).

Abbreviations: $\mathrm{cg}$ - cement gland; $\mathrm{Sp}$ - Saefftigen's pouch; sv — seminal vesicle. Scale bar: A-B, D $-2 \mu \mathrm{m}$; C $0.5 \mu \mathrm{m}$.

Рис. 6. Ультраструктура семенного пузырька и цементной железы цистаканта Neoechinorhynchus beringianus. A-D - электронная микроскопия. A - продольный срез цементной железы, мешка Сэфтигена, семенного пузырька; В - участок семенного пузырька с белковыми гранулами (звездочки) и жгутиками сперматозоидов (стрелки); С - жгутики сперматозоидов (стрелки) и конденсированный хроматин (наконечник стрелки) в семенном пузырьке при большом увеличении; D - участок цементной железы с цементными гранулами (стрелки) при большом увеличении.

Обозначения: $\mathrm{cg}$ — цементная железа; Sp — мешок Сэфтигена; sv — семенной пузырек. Масштаб: A-B, D - 2 мкм; С $-0,5$ мкм.

the peripheral parts of the spermatozoon bodies (Fig. 6C). These features indicated that the seminal vesicle was filled with mature sperma- tozoa. The cement gland contains secretory granules with diameters of up to $0.8 \mathrm{mkm}$ (Fig. 6D) surrounded by membranes. 


\section{Ecological data}

During our previous experimental study on the life cycle of $N$. beringianus, we found that temperature significantly affected the rate of larval development. At temperatures of 10, 15 and $20{ }^{\circ} \mathrm{C}$, the durations of development up to the cystacanth stage in ostracods were 50,32 and 25 days, respectively (Mikhailova, 2015). All females obtained experimentally had only compact ovaries, and males contained no sperm.

Comparison of cystacanths from the natural population in Lake Chernoye that were obtained in several samples of intermediate hosts showed that two categories of sexual maturity can be distinguished in each sex: 1) females with unfragmented ovaries and females with ovarian balls; and 2) immature males without sperm and mature males with sperm-filled seminal vesicles. Table 1 contains data showing that the occurrences of these categories vary significantly from year to year, which indicated that certain natural factors affect the maturation process.

It is highly likely that maturation, similar to larval development, depends on temperature conditions. The data on samples collected from ostracods at the beginning of the warm season (29.05.2010 and 18.06.2015 in Table 1) indicated the state of maturity of overwintered cystacanths. The occurrences of sexually developed specimens in these samples differed markedly. It should be noted that ostracods winter in shallow areas where, during the entire freezeover period (about eight months, from October to May inclusive) temperatures are usually below $0{ }^{\circ} \mathrm{C}$. It is logical to assume that both the larval development and maturation of the worms' gonads occur only at positive temperatures and that thermal conditions are most important at the end of the previous warm period (September) and the beginning of the current one (May).

According to data from the nearest weather station, the inter-annual fluctuations in mean monthly air temperatures in September and May are 5.1 and $4.9^{\circ} \mathrm{C}$, respectively (Climate handbook, 1969). Before wintering, the average temperatures in 2009/2010 and 2014/2015 differed only slightly ( 4.8 and $5.8^{\circ} \mathrm{C}$, respectively). In contrast, in May, the difference was significant: in 2010 the average temperature was $5.4^{\circ} \mathrm{C}$, and in 2015 it was only $-0.3^{\circ} \mathrm{C}$. Certainly, this could have restrained the cystacanths' development at the beginning of the 2015 season.

Table 1. The occurrences of cystacanths at different stages of maturity in samplings of ostracods from Lake Chernoye.

Таблица 1. Встречаемость цистакантов различной степени половой зрелости в остракодах из оз. Черное.

\begin{tabular}{|c|c|c|c|c|c|c|}
\hline \multirow{2}{*}{ Date } & \multicolumn{3}{|c|}{ Females } & \multicolumn{3}{c|}{ Males } \\
\cline { 2 - 7 } & $\begin{array}{c}\text { No. of } \\
\text { specimens }\end{array}$ & $\begin{array}{c}\text { Unfragmented } \\
\text { ovary }\end{array}$ & $\begin{array}{c}\text { Ovarian } \\
\text { balls }\end{array}$ & $\begin{array}{c}\text { No. of } \\
\text { specimens }\end{array}$ & Immature & Mature \\
\hline 25.08 .1999 & 86 & $47 \%$ & $53 \%$ & 80 & $76 \%$ & $24 \%$ \\
\hline 29.05 .2010 & 56 & $22 \%$ & $78 \%$ & 45 & $18 \%$ & $82 \%$ \\
\hline 18.06 .2015 & 52 & $71 \%$ & $29 \%$ & 56 & $79 \%$ & $21 \%$ \\
\hline
\end{tabular}

Table 2. The occurrences of juvenile females and males at different stages of maturity in sticklebacks from Lake Chernoye.

Таблица 2. Встречаемость ювенильных самок и самцов различных стадий зрелости в колюшках из оз. Черное.

\begin{tabular}{|c|c|c|c|c|c|c|}
\hline & \multicolumn{4}{|c|}{ Females } & \multicolumn{2}{c|}{ Males } \\
\cline { 2 - 7 } & $\begin{array}{c}\text { No. of } \\
\text { specimens }\end{array}$ & $\begin{array}{c}\text { No. of } \\
\text { juveniles }\end{array}$ & Ovary & $\begin{array}{c}\text { Ovarian } \\
\text { balls }\end{array}$ & $\begin{array}{c}\text { No. of } \\
\text { specimens }\end{array}$ & $\begin{array}{c}\text { No. of } \\
\text { juveniles }\end{array}$ \\
\hline 19.07 .2013 & 108 & 9 & - & $100 \%$ & 85 & 5 \\
\hline 11.08 .2013 & 157 & 91 & $28 \%$ & $72 \%$ & 145 & 52 \\
\hline 10.09 .2013 & 264 & 103 & $9 \%$ & $91 \%$ & 242 & 17 \\
\hline
\end{tabular}


Study of changes in the maturation of acanthocephalans taken from sticklebacks during the 2013 warm period showed that the fish contained juvenile females at various stages of sexual development and both immature and mature males (Table 2).

The presence in definitive hosts of both females with unfragmented ovaries and males without sperm suggests that infectivity of cystacanths does not depend on the degree of development of their reproductive systems. In addition, sexual maturation can begin in intermediate hosts and then continue in definitive ones.

\section{Discussion}

The study of the fine morphology of the seminal vesicles of $N$. beringianus cystacanths showed that in some specimens the vesicles were filled with spermatozoa and the ultrastructure of the cement glands indicated that secretion was in progress. This provided definite ultrastructural evidence regarding the maturation of males in intermediate hosts. Given the presence of mature males in ostracods collected at various times, this can be considered a natural phenomenon of the ecology of $N$. beringianus populations in cold climates.

In addition, the study noted the successive transformation stages of the compact ovary in female cystacanths before breaking up into ovarian balls. This indicated that their reproductive systems develop inside intermediate hosts. The same transformations can be observed in females from definitive hosts. Therefore, further comparative study of oogenesis on the cytological level is necessary. Crompton (1985) obtained data on the structure of ovarian balls mainly from adult-stage acanthocephalans taken from the intestines of definitive hosts. Precocious ovary fragmentation, of which examples were given above, takes place during larval development before completion of the cystacanth stage and is apparently genetically caused. However, there is not enough data to characterize the taxonomic groups of Acanthocephala by that feature.

Nevertheless, numerous data on representatives of the genus Neoechinorhynchus confirm that the gonads of juvenile females established in definitive hosts present with compact ovaries. This means that for infective cystacanths of these acanthocephalans, the presence of unfragmented ovaries is the norm.

Steinsträsser (1936) paid special attention to clarifying the origination of ovarian balls in N. rutili (Müller, 1780), since there was no clear idea about the process at that time. Steinsträsser examined females of various ages from trout intestines and concluded that the appearance of ovarian balls was the result of division of the spherical ovaries found in young forms. According to observations by Merritt \& Pratt (1964), fragmentation of ovarian spheres indicated the onset of maturity in female $N$. rutili. Ovarian division into balls was seen two weeks after experimental infection of fish with infected ostracods. As Figure 8 shows, at the age of 48-57 days, experimentally grown female cystacanths had compact ovaries. Amin \& Vignieri's (1986) detailed study of the development and growth of adult-stage $N$. cylindratus (Van Cleave, 1913) Van Cleave 1919 distinguished two categories of juvenile females: one with compact ovaries and one with ovarian balls. The former was the primary stage of development. Many authors have noted a category of females with compact ovaries in populations of $\mathrm{NeO}$ echinorhynchus species on various continents while studying the seasonal cycles of worms in definitive hosts. Among them are N. rutili in Europe (Moravec, 1984; Lassière, 1989), N. qinghaiensis Liu, Wang et Yang, 1981 in Asia (Yang Tingbao, Liao Xianghua, 2001), N. pungitius Dechtiar, 1971 in North America (Lasee, 1989) and N. pimelodi Brasil-Sato et Pavanelli, 1998 in South America (Brasil-Sato, Pavanelli, 1999). Given all these, one can conclude that ovarian division into balls at the cystacanth stage in species in which the infective larva have unfragmented ovaries should be considered as advanced development of the parasites.

Regarding the paratenic hosts, it is generally accepted that their parasites retain levels of development corresponding to those of the cystacanths (Dogiel, 1981; Schmidt, 1985). However, there are examples of advanced develop- 
ment of representatives of the genus Neoechinorhynchus in paratenic hosts.

Ward (1940), who studied encysted specimens of $N$. cylindratus from the livers of bluegill bass Lepomis pallidus (Mitchill), reported, that four of seven females had 'not dissociated' ovaries, and three had ovarian balls. Juvenile females with ovarian balls were also found in older fly larvae Sialis lutaria (L.), paratenic hosts of $N$. rutili in Scotland (Lassière, 1988). In addition, this work contains a photograph of a live male from the same host, and although the author did not comment upon it, the reader can see that both the seminal vesicle and the cement reservoir are filled with content. Therefore, the maturation of male cystacanths noted in the present study apparently is not unique to $N$. beringianus.

Several authors have discussed the question of the biological significance of advanced development in intermediate hosts. Peura et al. (1986) proposed that it provides the opportunity to become established in a variety of definitive hosts and so favors the survival and spread of the parasite. Kennedy (2006) connected advanced sexual development in the cystacanth stage of F. necturorum with the short lifespan of adult worms that parasitize only larval salamanders and cannot survive the metamorphosis of their hosts.

To explain the expedience of the advanced development of $N$. beringianus in intermediate hosts, we propose that environmental climatic conditions are of primary importance. Overwintering of ostracods occurs in habitats where temperatures stay below $0{ }^{\circ} \mathrm{C}$ for most of the year, and the advanced sexual development of acanthocephalans in these ostracods makes the acanthocephalans capable of immediate reproduction in fishes. While located in the intermediate host and awaiting transmission via the food chain, the infective cystacanth continues its development and enters the definitive host ready to copulate.

Chubb et al. (2010) analyzed parasites' life cycles, postulating two options for their extension by incorporating a new host: 1) being inserted below the definitive host (downward incorporation) and becoming the intermediate host, or 2) being added above it (upward incorporation) and becoming a new definitive host.

Considering the ontogenesis of the acanthocephalans studied, one can note the continuity of their development after metamorphosis occurs in intermediate hosts. Reproduction is impeded only by the impossibility of contact between males and females. In our opinion, the advanced development of parasites in intermediate hosts testifies to the upward incorporation of a definitive host into the Acanthocephala life cycle.

\section{Acknowledgements}

We thank the anonymous reviewers for helpful comments on this manuscript. This investigation was supported by the Russian Foundation of Fundamental Researches, grant no. 1504-01418; by Presidium of Far Eastern Branch of the Russian Academy of Sciences, grant no. 15-I-6-015o.

\section{References}

Amin O.M., Burns L.A., Redlin M.J. 1980. The ecology of Acanthocephalus parksidei Amin, 1975 (Acanthocephala: Echinorhynchidae) in its isopod intermediate host // Proc. Helm. Soc. Wash. Vol.47. P.37-46.

Amin O.M., Vignieri J.C. 1986. Acanthocephala from lake fishes in Wisconsin: Numerical and structuralfunctional relationships of the giant nuclei in $\mathrm{NeO}$ echinorhynchus cylindratus (Neoechinorhynchidae) // J. Parasitol. Vol.72. P.88-94.

Andryuk L.V. 1979a. [The life cycle of Acanthocephalus anguillae] // Zool. Zhurn. Vol.58. No.2. P.168-173 [in Russian].

Andryuk L.V. 1979b. [The developmental cycle of Acanthocephalus lucii (Acanthocephala: Echinorhynchidae)] // Parazitologiya. Vol.13. No.5. P.530539 [in Russian, with English summary].

Asaolu S.O., Whitfield P.J., Crompton D.W.T., Maxwell L. 1981. Observations on the development of the ovarian balls of Moniliformis (Acanthocephala) // Parasitol. Vol.83. P.23-32.

Awachie J.B. 1966. The development and life history of Echinorhynchus truttae Schrank, 1788 (Acanthocephala) // J. Helminthol. Vol.15. P.11-32.

Brasil-Sato M.C., Pavanelli G.C. 1999. // Ecological and reproductive aspects of Neoechinorhynchus pimelodi Brasil-Sato and Pavanelli (Eoacanthocephala, Neoechinorhynchidae) of Pimelodus maculatus Lacépède (Siluroidei, Pimeloidae) of the Sáo Francisco river, Brazil // Revista Brasileira de Zoologia. Vol.16. No.1. P.73-82. 
Brattey J. 1980. Preliminary observations on larval Acanthocephalus lucii (Müller, 1776) (Acanthocephala: Echinorhynchidae) in the isopod Asellus aquaticus (L.) // Parasitol. Vol.81. P.xlix-1.

Brattey J. 1986. Life history and population biology of larval Acanthocephalus lucii (Acanthocephala: Echinorhynchidae) in the isopod Asellus aquaticus // J. Parasitol. Vol.72. P.633-645.

Cable R.N., Dill W.T. 1967. The morphology and the life history of Paulisentis fractus Van Cleave and Bangham, 1949 (Acanthocephala: Neoechinorhynchidae) // J. Parasitol. Vol.53. P.810-817.

Chubb J.C., Ball M.A., Parker G.A. 2010. Living in intermediate hosts: evolutionary adaptations in larval helminthes // Trends Parasitol. Vol.26. P.93-102.

[Climate handbook of USSR]. 1969. Fasc.33. Pt.1. Magadan. 305 p. [in Russian]

Crompton D.W.T. 1985. Reproduction // D.W.T. Crompton, B.B. Nickol (eds.). Biology of the Acanthocephala. London: Cambridge University Press. P.213-271.

DeMont D.J., Corkum K.C. 1982. The life cycle of Octospiniferoides chandleri Bullock, 1957 (Acanthocephala: Neoechinorhynchidae) with some observations on parasite induced, photophilic behavior in ostracods // J. Parasitol. Vol.68. P.125-130.

Dezfuli B.S., Onestini S., Carcupino M., Mischiati C. 1998. The cement apparatus of larvae and adult Pomphorhyncus laevis (Acanthocephala: Palaeacanthocephala) // Parasitol. Vol.116. P.437-447.

Dezfuli B.S., Simoni E., Mischiati C. 2001. The cement apparatus of larval and adult Acanthocephalus anguillae (Acanthocephala), with notes on the copulatory cap and origin of gland secretion // Par. Res. Vol.87. No.4. P.299-305.

Dogiel V.A. 1981. [Zoology of the invertebrates]. Moscow: Vysshaja Shkola Publ. 606 p. [in Russian]

Kennedy C.R. 2006. Ecology of the Acanthocephala. Cambridge: Cambridge University Press. 249 p.

Keppner E.J. 1974. The life history of Paulisentis missouriensis $\mathrm{n}$. sp. (Acanthocephala: Neoechinorhynchidae) from the creek chub Semotilus atromaculatus // Trans. Am. Micr. Soc. Vol.93. P.89-100.

Lasee B.S. 1989. Seasonal population dynamics and maturation of Neoechinorhynchus pungitius (Acanthocephala: Neoechinorhynchidae) infecting brook stickleback, Culaea inconstans, from Sioux Creek, Wisconsin, U.S.A. // Can. J. of Zool. Vol.67. No.3. P.590-595.

Lassière O.L. 1988. Host-parasite relationships between larval Sialis lutaria (Megaloptera) and Neoechinorhynchus rutili (Acanthocephala) // Parasitol. Vol.97. P.331-338.

Lassière O.L. 1989. The ecology of Neoechinorhynchus rutili (Acanthocephala) in Scottish freshwater lochs. PhD Thesis. University of Glasgow. 442 p.

Merritt Sh.V., Pratt I. 1964. The life history of Neoechinorhynchus rutili and its development in the intermediate host (Acanthocephala: Neoechinorhynchidae) // J. Parasitol. Vol.50. P.394-400.

Mikhailova E.I. 2015. [The acanthocephalans of genus Neoechinorhynchus inhabiting north-eastern Asia (tax- onomy, zoogeography, ecology)]. PhD Thesis. Zoological Institute of RAS. 186 p. [in Russian]

Moore D.V. 1946. Studies on the life history and development of Moniliformis dubius (Meyer, 1933) // J. Parasitol. Vol.32. P.257-271.

Moore D.V. 1962. Morphology, life history, and development of the acanthocephalan Mediorhynchus grandis Van Cleave, 1916 // J. Parasitol. Vol.48. P.76-86.

Moravec F. 1984. Seasonal occurrence and maturation of Neoechinorhynchus rutili (Müller, 1780) (Acanthocephala) in carp (Cyprinus carpio L.) of the Mácha Lake fishpond system Czechoslovakia // Helminthologia. Vol.21. P.55-65.

Nickol B.B., Heard R.W. 1973. Host-parasite relationships of Fessisentis necturorum (Acanthocephala: Fessisentidae) // Proc. Helm. Soc. Wash. Vol.40. P.204-208.

Petrochenko V.I. 1956. [Acanthocephala of domestic and wild animals]. Leningrad: Izdatel'stvo Akademii Nauk SSSR Publ. Vol.1. 435 p. [in Russian]

Peura R., Valtonen E.T., Crompton D.W.T. 1986. Ovarian tissue in juvenile palaeacanthocephalans: Corynosoma semerme, C. strumosum and Echinorhynchus gadi // Parasitol. Vol.93. P.471-480.

Schmidt G.D. 1985. Development and life cycles // D.W.T. Crompton, B.B. Nickol (eds.). Biology of the Acanthocephala. London: Cambridge University Press. P. 213-271.

Schmidt-Rhaesa A. 2007. The evolution of organ systems. New York: Oxford University Press. 385 p.

Skrjabin K.I., Schulz R.S., 1940. [Fundamentals of general helminthology] Moscow: Sel'hozgiz Publ. 470 p. [in Russian]

Steinsträsser W. 1936. Acanthocephalen als Forellenparasiten // Z. Fischerei. Vol.34. P.174-212 [in German].

Uglem G.L., Larson O.R. 1969. The life history and larval development of Neoechinorhynchus saginatus Van Cleave and Bangham, 1949 (Acanthocephala: Neoechinorhynchidae// J. Parasitol. Vol.55. P.1212-1217.

Ward H.L. 1940. Studies on the life history of Neoechinorhynchus cylindratus (Van Cleave, 1913) (Acanthocephala) // Trans. Am. Micr. Soc. Vol.59. P.327-347.

Weather archive in Talaya. URL: http://rp5.ru/Weather archive_in_Talaya

Whitfield P.J. 1971. Spermiogenesis and spermatozoan ultrastructure in Polymorphus minutus (Acanthocephala) // Parasitol. Vol.62. P.415-430.

Wilson B.A., Hubschman J.H. 1985. Host-parasite relationships of Tanaorhamphus longirostris (Acanthocephala: Neoechinorhynchidae) in the intermediate host, Diaptomus pallidus (Crustacea: Copepoda) // Proc. Helm. Soc. Wash. Vol.52. P.71-75.

Yang Tingbao, Liao Xianghua. 2001. Seasonal population dynamics of Neoechinorhynchus qinghaiensis in the carp, Gymnocyris przewalskii przewalskii, from Qinghai Lake, China // J. Helm. Vol.75. P.93-98.

Responsible editor N.M. Biserova 